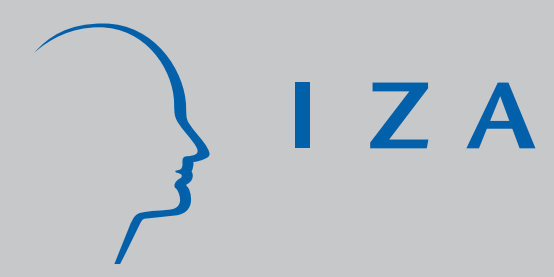

IZA DP No. 2226

The Tax System Incidence on Unemployment: A Country-Specific Analysis for the OECD Economies

J osé Ramón García

Hector Sala

July 2006 


\title{
The Tax System Incidence on Unemployment: A Country-Specific Analysis for the OECD Economies
}

\author{
José Ramón García \\ Universitat de València \\ Hector Sala \\ Universitat Autònoma de Barcelona \\ and IZA Bonn
}

Discussion Paper No. 2226

July 2006

IZA

P.O. Box 7240

53072 Bonn

Germany

Phone: +49-228-3894-0

Fax: +49-228-3894-180

Email: iza@iza.org

Any opinions expressed here are those of the author(s) and not those of the institute. Research disseminated by IZA may include views on policy, but the institute itself takes no institutional policy positions.

The Institute for the Study of Labor (IZA) in Bonn is a local and virtual international research center and a place of communication between science, politics and business. IZA is an independent nonprofit company supported by Deutsche Post World Net. The center is associated with the University of Bonn and offers a stimulating research environment through its research networks, research support, and visitors and doctoral programs. IZA engages in (i) original and internationally competitive research in all fields of labor economics, (ii) development of policy concepts, and (iii) dissemination of research results and concepts to the interested public.

IZA Discussion Papers often represent preliminary work and are circulated to encourage discussion. Citation of such a paper should account for its provisional character. A revised version may be available directly from the author. 


\section{ABSTRACT}

\section{The Tax System Incidence on Unemployment: A Country-Specific Analysis for the OECD Economies*}

This paper provides a detailed analysis on the incidence of the tax structure on the labor market. To do so it goes beyond the traditional examination of the 'level' effect of the fiscal wedge and considers a 'composition' effect defined as a payroll tax bias (PTB): the proportion of payroll taxes paid by employees with respect to the one paid by firms. We develop a right-to-manage model encompassing different wage bargaining systems and the incidence of different type of taxes. Controlling for demand-side and supply-side determinants of unemployment, we show that the PTB plays a significant role in explaining unemployment in the continental European countries, but not in the Nordic nor the AngloSaxon ones. We also show that there is no relationship between the incidence of the PTB and unemployment persistence, even though there is a positive one with respect to the level of the fiscal wedge.

JEL Classification: E24, E62

Keywords: unemployment, unemployment persistence, fiscal wedge, payroll tax bias

Corresponding author:

Hector Sala

Department d'Economia Aplicada

Universitat Autònoma de Barcelona

08193 Bellaterra

Spain

E-mail: hector.sala@uab.es

\footnotetext{
* Hector Sala is grateful to the Spanish Ministry of Education for financial support through grant SEC2003-7928.
} 


\section{Introduction}

This paper examines the incidence of the tax structure on unemployment. This topic has been widely analyzed but with two restraining features. The first one is the conventional attention to the 'level' effect of the fiscal wedge on the labor market. Our analysis goes beyond this level effect and seeks to evaluate a 'composition' effect defined as a Payroll Tax Bias (PTB). The question we attempt to answer is the following: is the composition of social security contributions levied on workers and firms neutral, or does it affect unemployment? The second restraining feature is the standard estimation of static models for a pool of countries: five-year means of the time series are commonly used on account of institutional time invariability; this narrows dramatically the sample period, requires the enlargement of the cross-section units of analysis and forces to consider a large number of countries. As a consequence, the impact of taxes on unemployment is typically evaluated under substantial restrictions such as abstraction of dynamics and common slope coefficients. In contrast to this procedure, our empirical methodology relies on a country-specific dynamic analysis such that (i) when we answer the question above we are allowed to be precise in judging the consequences of the fiscal wedge and the PTB; and (ii) we are able to assess the relationship between the relevance of the PTB and unemployment persistence.

This analysis is central in a context where the continuous increase in life expectancy leads to a steep increase of the old age dependency ratio with immediate financial consequences on social security systems (the pay-as-you-go pension scheme, health services and other social programmes financed by general taxes that are geared to the elderly). Since the tax system hurts competitiveness, a number of reforms to encourage older persons to remain active and alleviate the fiscal challenges posed by ageing population have been implemented. This conundrum lies outside the scope of the paper, but our analysis may contribute to shed new light on this debate. In particular, to know if the tax composition to finance the social security system hurts unemployment or is neutral should be a useful insight for policy makers. The finding that the composition of social security contributions matters would raise the burden on the public finance and reduce the possibility of future reforms. On the contrary, the finding that this is relatively innocuous would give room for reforms beyond the ones that have mainly been implemented. This paper seeks to promote knowledge on this issue.

The trajectory of unemployment in the aftermath of the oil price shocks prompted the upsurge of a large amount of literature trying to explain the causes of its initial rise, of its subsequent persistence and, finally, the reasons of the different performance of the 'successful' and 'unsuccessful' countries in the 1990s. ${ }^{1}$ A salient feature of the

\footnotetext{
${ }^{1}$ See Blanchard (2006) for a revision of this literature.
} 
mainstream literature is that shocks, institutions and the interactions between the two are sufficient to account for these facts. In this context, what is relevant to this paper is the role of the labor taxation system as a principal institution. This role has been studied Nickell (1997), Nickell and Layard (1999), Elmeskov et al. (1998), Alesina and Perotti (1997), Daveri and Tabellini (2000) and Belot and Van Ours (2004), to name a few; they yield an unanimous conclusion: because the taxes increase unemployment, the implementation of taxation reforms reducing this burden would lead to a reduction in the unemployment rate.

These papers share several characteristics. First, they consider a global tax comprising taxation on both workers and firms. This implies that all tax rates have the same impact on wages (invariance of incidence proposition) and, as a consequence, there is no distinction between the different agents paying the taxes. Note that income taxes and the employees' social security contributions are taxes levied on the supply-side of the labor market, while payroll taxes or employers' social security contributions are levied on the demand-side of the market. Second, the estimated coefficients are common across countries (or groups of countries) and, thus, are biased or inaccurate. Third, they do not take into account the relationship between unemployment and the tax structure in a dynamic context allowing for unemployment persistence. We diverge (and contribute) to this literature in these three aspects.

Another stream of literature, just theoretical, takes into account the labor tax structure as a key element in wage setting and labor market performance. Some examples are Rasmussen (1997), Pissarides (1998), Muysken et al. (1999), Koskela and Schöb (1999), and Picard and Toulemonde (2001). We build-up on these papers and develop a right-to-manage model that considers the tax structure to be an important determinant of wages and unemployment. This model endorses our empirical analysis by: (i) tying unemployment benefits to past wage levels to allow dynamics; (ii) outlining the significance of several fiscal policy parameters, in particular the tax composition and the workers' perceptions of public transfers; and (iii) encompassing different wage bargaining systems to allow the analysis to be wide enough.

To encompass the incidence of the diverse tax systems across countries our model has two important features. The first one is that unions are able to internalize government transfers in exchange of taxes. ${ }^{2}$ This implies that the tax system is not forced to damage employment. For example in corporatist economies, such as the Nordic ones, taxes may be perceived as the counterpart of the welfare state. In that case, lower net wages are accepted on account of the public services received in exchange of taxes. Second, the model adopts an utilitarian approach because unions in some countries, for example the

\footnotetext{
${ }^{2}$ This is so via a parameter $(\phi)$ that captures the unions' (and workers') perception of the public transfers received in exchange of their tax payments.
} 
Anglo-Saxon ones, are not that relevant for wage bargaining. This approach implies that unions maximize the workers' utility function and, therefore, there is no need of a version of the model without unions (for example, to reflect the Anglo-Saxon wage bargaining system). Of course, and by implication, workers on their own are also able to internalize public services and the first feature -internalization- holds even in situations with weak or no unions -see, for example, Gruber (1997)-. Summing up, these two key features of the model make it suitable to provide a unified theoretical framework to endorse our empirical analysis on economies as diverse as the Nordic, the Anglo-Saxon and the continental European ones. ${ }^{3}$

It is important to note that we do not endeavor to provide an econometric replica of this model. It is nevertheless the case that it suits our empirical analysis for a crucial reason: it provides a benchmark whereby the unemployment impact of the tax structure (in particular of the different social security contributions paid by employers and employees for a given level of the tax wedge) can be evaluated.

Because we need cross-country comparability, we are bound to confine the pool of explanatory variables. This is the only restrictive feature of our empirical analysis, and yields us to capture demand-side influences on unemployment via inflation acceleration and supply-side influences via productivity growth. Apart from these variables the estimated equation for each country is dynamic and contains the level effect of the tax system (the fiscal wedge) and a composition effect (defined as the PTB).

The empirical findings confirm the well-known result that the fiscal wedge is not a main determinant of unemployment in the Anglo-Saxon and Nordic countries, in contrast to the continental European ones -see Alesina and Perotti (1997) and Daveri and Tabellini (2000)-. In this context, our results put forward a new finding: not only the fiscal wedge matters in the latter group, but also the PTB. The result for the first group of countries is commonly rationalized via their firm-level wage bargaining system which pictures an scenario close to a competitive market with inelastic labor supply: any tax rise is borne by workers, with very little effect on unemployment because the labor supply curve adjusts to labor demand shifts. The scenario for the second group is that of a high degree of centralization: the positive link between higher taxation and welfare benefits is internalized and taxes have a low distortionary impact; the wage setting curve adjusts to labor demand shifts caused by tax variations. Both situations, therefore, yield a similar outcome. In the continental European countries the distortionary effect of taxes on employment is rationalized via their industrial-level wage bargaining systems where there is no internalization and tax rises are shifted onto labor costs through higher wage claims.

\footnotetext{
${ }^{3}$ The criterion for this classification is not geographical but, along the lines of Daveri and Tabellini (2000), based on the type of wage bargaining system of the corresponding country. See tables 3 to 5 for the concrete allocation of the OECD economies to these groups.
} 
The first important novelty of our findings is the positive effect of the PTB on unemployment when taxes are distortionary: not only the level of the fiscal wedge matters, but also the specific composition of taxes. This seems a natural finding when there is a different unemployment elasticity with respect to the two components of the payroll taxes (levied on workers and firms). This is precisely how this result is rationalized in our model where the coefficient between these two elasticities differs from unity. Given our country-specific approach we are able to relate the incidence of the fiscal wedge and the PTB across countries to unemployment persistence (of course, this relationship only holds for continental Europe where these variables matter). Thus, the second novelty of our findings is that the stronger the impact of the fiscal wedge, the larger unemployment persistence whereas, on the contrary, there is no apparent relationship between persistence and the incidence of the PTB. These results are just a first step in the knowledge of the labor market PTB incidence. Nevertheless, taken at face value they would imply that there is room for tax system reforms aiming at composition changes without significant changes in firm's adjustment costs. It is the fiscal wedge as a whole (the level impact) what seems to be related to unemployment persistence, not the distribution of payroll taxes.

The rest of the paper is structured as follows. Section 2 presents the theoretical model. Section 3 presents the data and the stylized facts characterizing the evolution of the relevant variables in the OECD countries. Section 4 deals with the econometric analysis. Section 5 concludes.

\section{The model}

In this section we develop a right-to-manage model to examine how the tax structure affects unemployment ${ }^{4}$. This framework is commonly thought to be more suited to the European scenario where either the union density rate of workers or/and the coverage of collective bargaining are high. Nevertheless, the model we develop seeks to encompass other scenarios such as the Nordic countries one, with a centralized wage bargaining system, and the Anglo-Saxon countries one, with a decentralized system. It does so by placing particular significance to the workers' perception of the public services received in return of their taxes. It is well-known that unions (or workers on their own) can shift the tax burden paid by employees to the firms through higher wage demands. However, if on account of the public services they acquire, they perceive these taxes as compulsory savings or insurance premiums they will be willing to accept net wage cuts

\footnotetext{
${ }^{4}$ The basic idea of the right-to-manage model is that wages are negotiated between a union and a firm, and employment is managed by the firm once the wage has been determined in the wage bargaining process. See Nickell (1982) and Nickell and Andrews (1983) for details.
} 
and taxes will not hurt job creation.

Relevant contributions to this topic, such as Alesina and Perotti (1997) and Daveri and Tabellini (2000), consider the aggregate impact of taxes as a wage pressure factor. Our model also diverges in this particular feature and provides a detailed analysis considering different types of taxes: it is still the case that taxes rise firms' labor costs irrespective of whether they are borne by workers or firms, but in the wage bargaining process unions can only shift the tax rate on labor income and the component of social security contributions paid by workers; they cannot shift the component levied on firms, which is not subject to the wage bargaining process.

As shown next, these two considerations allow our setup to take into account different situations (across countries and types of taxes) related to the unemployment impact of the tax system.

\subsection{Firms}

The short run production function of the representative firm is ${ }^{5}$

$$
y_{t}=\theta_{t} l_{t}^{\alpha}
$$

where $y$ is the level of output, $l$ the employment rate, $\theta$ a productivity factor and $\alpha$ a parameter such that $\alpha<1$. Labor force and population are normalized to 1 so that $l=1-u, u$ being the rate of unemployment.

In the product market there is imperfect competition. Firms face isoelastic downward sloping demand curves that settle the aggregate price as follows

$$
y_{t}=D\left(p_{t}\right)=p_{t}^{-\eta}
$$

where $p$ is the product price of firms, $\eta$ the output demand elasticity and $\frac{1}{\eta}$ the firms' degree of monopoly power. Note that market power generates monopoly rents which may be captured by the employees in the form of higher wages (Layard et al., 1991). This implies that $\frac{1}{\eta}$ is a central parameter in the wage bargaining process, as highlighted in Belot and Van Ours (2004).

The aim of the representative firm is to maximize its profit function

$$
\operatorname{Max}_{l_{t}} \Pi_{t}=p_{t} y_{t}-l_{t} w_{t}\left(1+\tau_{t}^{s s f}\right)
$$

\footnotetext{
${ }^{5}$ Even though capital and labor are perfect substitutes in the long-run we abstain from an explicit consideration of the former. The aim of the model is to endorse our empirical analysis which, due to data limitations, does not take into account the role of capital stock. Instead productivity growth plays an important role, which of course also reflects changes in capital stock. This is captured by $\theta$ which should be given a general interpretation along these lines.
} 
where $w$ is the negotiated wage, $\tau^{s s f}$ is the payroll tax to be paid by firms for hired workers, and -according to (1) and (2)- $p_{t}=\left[y_{t}\right]^{-\frac{1}{\eta}}=\left[\theta_{t} l_{t}^{\alpha}\right]^{-\frac{1}{\eta}}$. Since firms have the right-to-manage, they maximize profits with respect to labor. This gives the following labor demand function

$$
l_{t}^{d}=\left[\frac{\left(1-\frac{1}{\eta}\right) \alpha \theta_{t}^{\left(1-\frac{1}{\eta}\right)}}{\left(1+\tau_{t}^{s s f}\right) w_{t}}\right]^{-\frac{1}{\eta}+(1-\alpha)}
$$

where $-\frac{\partial l_{t}}{\partial w_{t}} \frac{w_{t}}{l_{t}}=\epsilon_{l w}=\frac{1}{1-\alpha+\frac{\alpha}{\eta}}$ is the elasticity of employment with respect to wages. This expression shows that employment depends negatively on the labor cost to be paid by the employer $\left(1+\tau^{s s f}\right) w_{t}$ and positively on (i) labor-intensiveness $(\alpha)$ in the production function and (ii) the productivity factor $\theta$.

\subsection{Workers and unions}

To model union preferences we follow the widely used utilitarian approach where unions care on their member's welfare. ${ }^{6}$ We assume that (i) unions operate at the firm or sector level, and (ii) their members are identical, not risk-averse and can either be employed or unemployed.

If employed they supply one unit of work and receive a gross wage $(w)$ subject to a wage tax $\left(\tau^{l}\right)$ comprising the portion of social security contribution paid by employees $\left(\tau^{s s e}\right)$ and the income tax $\left(\tau^{e}\right)$. The net-of-tax wage is thus $w\left(1-\tau^{l}\right)$. If unemployed, they obtain an alternative income $(S)$ which can interpreted either as the competitive wage, as a wage paid in another sector, or as an unemployment compensation. ${ }^{7}$ This alternative income is taxed by $\lambda \tau^{l}$, with $0 \leq \lambda \leq 1,{ }^{8}$ so that the net-of-tax outside option is given by $\left(1-\lambda \tau^{l}\right) S$.

We consider the welfare state as the counterpart of the tax system. In particular, we have in mind public transfers $(T r)$ to households on account of education, health services or pensions, which we assume to be a constant proportion $(\sigma)$ of wages and employment:

$$
\operatorname{Tr}_{t}=\sigma_{t} w_{t} l_{t}
$$

where $\sigma$ is an exogenous parameter chosen by the government. The latter is important because it enacts a connection between taxes paid by (or on behalf of) workers and their expected benefits in return of these taxes. The clearest example are social security contributions which are a benefit-linked payroll tax. This connection can be realized

\footnotetext{
${ }^{6}$ See Oswald (1985), Farber (1986) and Booth (1995).

${ }^{7}$ In a general equilibrium setting, the alternative income is a combination of some or all of these components (Manning, 1990).

${ }^{8} \lambda$ is assumed to be less than one because unemployment benefits are smaller than wages. This formulation allows to increase the progressiveness of taxes paid by workers between two different labor situations.
} 
via two channels, the first one relying on the role of unions and the second one on the workers' perceptions on these transfers themselves.

- Unions can be assumed to internalize some (or all) government transfers. The degree to which this happens is measured with $\phi$, with $0 \preceq \phi \preceq 1$, which allows to capture some features of the social security systems in the industrialized countries. For example, higher values of $\phi$ should be associated with more corporatist economies where taxation is found to be less distortionary. On the contrary, in countries where wage bargaining is decentralized or non-existent this parameter is zero. Empirical evidence for this effect is given in Summers et al. (1993), Alesina and Perotti (1997), Daveri and Tabellini (2000) and Belot and Van Ours (2004).

- In labor market models with no unions and competitive labor supply the value of $\phi$ has also been related to the way workers value payroll taxes and their counterparts in the form of benefits. For example, in Gruber (1997) and Summers (1989) there is a full linkage between taxes and benefits which prevents higher labor taxes to be translated into higher wages and lower employment. ${ }^{9}$

To sum up, the tax system effect on the labor market crucially hinges on two parameters: $\sigma$, which is purely quantitative, and $\phi$, which is purely qualitative. When both are high, unions (workers) are likely to accept higher taxes and lower net wages on account of the subsequent stream of public transfers they will receive. In that case, there will be no employment effects ${ }^{10}$. It is important to remark that $\phi$ is time-varying and different across countries depending, among other things, on how centralized is collective bargaining and how public services in return of taxes are valued by workers. ${ }^{11}$

Taking into account the aforementioned points, we conceive the union's objective function as follows:

$$
V_{t}^{*}=l_{t}\left[w_{t}\left(1-\tau_{t}^{l}\right)+\phi_{t} \sigma_{t} w_{t}\right]+\left(1-l_{t}\right)\left[S_{t}\left(1-\lambda_{t} \tau_{t}^{l}\right)\right]
$$

\subsection{The labor market}

Following the right-to-manage model, unions and firms bargain over the wage level, taking into account the labor demand curve. We follow the standard practice in the literature and assume that the threat points for the firm and the trade union are,

\footnotetext{
${ }^{9}$ According to Gruber (1997) if benefits are generalized to all people, the tax-benefits linkage is reduced ( $\phi$ in our model becomes lower) because workers perceive public transfers not directly related to their taxes.

${ }^{10}$ Note that our formulation allows all type of taxes to be internalized (since all of them contribute to finance public services).

${ }^{11}$ See Doménech and García (2006) for a more detailed discussion on this issue.
} 
respectively, $\Pi^{0}=0$ and $V_{t}^{0}=\left[S_{t}\left(1-\lambda \tau_{t}^{l}\right)\right]$. Thus, wages solve the following Nash bargaining problem:

$$
\begin{aligned}
& \underset{w_{t}}{\operatorname{Max}} \Omega_{t} \\
& \text { s.t. } \Pi_{l}=0,
\end{aligned}
$$

where parameter $\beta$ represents the relative bargaining power of the union, $\Pi_{l}$ is the first order condition derived from the profit function (3), and $V$ is the net income maximized by the trade union:

$$
V_{t}=V_{t}^{*}-V_{t}^{0}=l_{t}\left[w_{t}\left(1-\tau_{t}^{l}+\phi \sigma_{t}\right)-S_{t}\left(1-\lambda \tau_{t}^{l}\right)\right]
$$

For an interior solution, the maximization of the logarithm of the generalized Nash criterion gives the first-order condition:

$$
\Omega_{w}=0 \Leftrightarrow \beta \frac{V_{w}}{V_{t}}+(1-\beta) \frac{\Pi_{w}}{\Pi}=0 .
$$

The solution to the wage bargaining problem yields the following negotiated wage (see the Appendix for the demonstration):

$$
w_{t}=\frac{S_{t}\left(1-\lambda \tau^{l}\right)}{\left(1-\tau^{l}+\phi \sigma_{t}\right)\left[1-\frac{\beta}{\epsilon_{l w}\left[\left(1-\frac{1}{\eta}\right)(1-\beta) \alpha+\beta\right]}\right]}
$$

Note that the higher the degree of monopoly power in the commodity market, $\frac{1}{\eta}$, the higher is the negotiated wage in concordance with what we anticipated below (2).

Substitution of the wage rate (10) in the labor demand equation (4) together with the definition of unemployment $(l=1-u)$ immediately entails:

$$
\left.u_{t}=1-\left[\frac{\left(1-\frac{1}{\eta}\right) \alpha \theta_{t}^{\left(1-\frac{1}{\eta}\right)}\left(1-\tau^{l}+\phi_{t} \sigma_{t}\right)\left[1-\frac{\beta}{\epsilon_{l w}\left[\left(1-\frac{1}{\eta}\right)(1-\beta) \alpha+\beta\right]}\right]}{\left(1+\tau_{t}^{s s f}\right) S_{t}\left(1-\lambda \tau^{l}\right)}\right]\right]^{\frac{\frac{1}{\eta}+(1-\alpha)}{\eta}}
$$

According to (11) the equilibrium unemployment rate depends on: (i) the net outside option of trade unions $S\left(1-\lambda \tau^{l}\right)$; (ii) the proportional tax income $\tau^{l}$; (iii) the wage elasticity of labor demand $\epsilon_{l w}$; (iv) the firms' market power $\frac{1}{\eta}$; (iv) the degree of internalization of public expenditures $\phi$; and (v) the productivity factor $\theta$.

This formulation allows to highlight the unemployment impact of a tax structure based on the statutory tax between employer and employees. As Rasmussen (1997), Muysken and van Veen (1996), Koskela and Schöb (1999) and Picard and Toulemonde (2001) have shown, this frame of analysis seems to be the most suitable one when dealing with non-competitive markets. 


\subsection{Unemployment effects of labor taxation}

To discuss the different unemployment effects of each type of tax considered we perform a partial equilibrium analysis where, from the viewpoint of a single firm, the outside option of its workers is not affected by its particular wage setting behavior. Hence, we look at the unemployment elasticity with respect to each tax.

Departing from (11), the elasticity of unemployment with respect to the payroll tax levied on workers $\left(\varepsilon_{u \tau^{s s e}}\right)$ can be shown to be:

$$
\varepsilon_{u \tau^{s s e}}=\frac{\partial u}{\partial \tau^{s s e}} \frac{\tau^{s s e}}{u}=\frac{1}{(1-\alpha)+\frac{\alpha}{\eta}} \frac{1-u}{u} \tau^{s s e}\left[\frac{1}{\left(1-\tau^{l}+\phi_{t} \sigma_{t}\right)}-\frac{\lambda_{t}}{\left(1-\lambda_{t} \tau^{l}\right)}\right] .
$$

This expression emphasizes the diversity of results that can be achieved when analyzing economies with different tax structures and institutions. In particular, for the centralized wage bargaining system of the Nordic countries it seems sensible to expect higher values of $\phi$ and $\lambda$. If this is the case and unions internalize social expenditures, we should expect that the tax burden $\left(\tau^{s s e}\right)$ is not translated into higher wages and the labor market is not hurt by a demanding tax system such as the Nordic one. ${ }^{12}$

In turn, the elasticity of unemployment with respect to the payroll tax levied on firms $\left(\tau^{s s f}\right)$ yields:

$$
\varepsilon_{u \tau^{s s f}}=\frac{\partial u}{\partial \tau^{s s f}} \frac{\tau^{s s f}}{u}=-\frac{1}{\frac{(1-\alpha)}{\eta}+\alpha} \frac{1-u}{u} \frac{\tau^{s s f}}{1+\tau^{s s f}}
$$

Along the lines of expression (12), this indicates that the tax system impact varies according to the tax level reached by $\tau^{s s f}$ and the elasticity of unemployment with respect to wages. ${ }^{13}$

From a methodological viewpoint, it is important to note that this framework allows a disaggregated evaluation of the incidence of the tax system on unemployment. In particular, we can examine the effects of the payroll tax component levied on employees $\left(\tau^{s s e}\right)$ with respect to the one levied on firms $\left(\tau^{s s f}\right)$ by comparing both elasticities:

$$
\xi_{t}=\frac{\varepsilon_{u \tau^{l}}}{\varepsilon_{u \tau^{s s e}}}=\frac{\tau^{s s e}}{\tau^{s s f}}\left[\frac{1}{\left(1-\tau^{l}+\phi_{t} \sigma_{t}\right)}-\frac{\lambda_{t}}{\left(1-\lambda_{t} \tau^{l}\right)}\right]\left(1+\tau^{s s f}\right) .
$$

This result deserves three important remarks. First, the two elements in equation (14) are the proportion of taxes levied on workers with respect to those levied on firms, $\frac{\tau^{s s e}}{\tau^{s s f}}$,

\footnotetext{
${ }^{12}$ When the social security stops acting as an insurance system, contributions start being perceived as a standard tax. This reduces the expected value of $\phi$ and may contribute to explain some of our empirical findings (see below).

${ }^{13}$ This result, of course, depends on the assumption we have made on the production function. Equation (13) would be more complex had we assumed a CES production function. In particular, as shown in Koskela and Schöb (1999), the payroll tax would also affect the negotiated wage.
} 
and the tax wedge, $\left[\frac{\lambda_{t}}{\left(1-\lambda_{t} \tau^{l}\right)}-\frac{1}{\left(1-\tau^{l}+\phi_{t} \sigma_{t}\right)}\right]\left(1+\tau^{s s f}\right)$. Second, $\xi_{t} \neq 1$ which implies there is no neutrality in the tax system. Third, it is easy to see that, if $\phi_{t}=\lambda_{t}=0$, the relationship between elasticities becomes

$$
\xi_{t}=\frac{\tau^{s s e}}{\tau^{s s f}} \frac{\left(1+\tau^{s s f}\right)}{\left(1-\tau^{l}\right)}
$$

The fact that $\xi_{t} \neq 1$ is a salient result of our analysis because it implies that a shift in taxation from employers to employees (leaving the tax wedge constant) can alter unemployment outcomes just by affecting the structure of the tax system. This can be readily seen from (15) showing that the elasticity of imposition levied on workers is higher than the one levied on firms and, therefore, $\xi>1$. The same holds for equation (14), but this effect depends on the values of $\phi$ and $\lambda$ which, in turn, allows the scenario of the Nordic countries to be considered (the closer $\phi$ is to 1 , the lower the unemployment effects of the fiscal wedge and the PTB).

This framework endorses our empirical analysis in two ways. First, our model shows that the unemployment impact of the tax system depends on (i) the level of each tax rate and (ii) the unions' (workers') internalization of the stream of public services derived from the tax system. Second, it justifies the presence of the PTB as well as the fiscal wedge in the estimated reduced-form unemployment equation.

\subsection{General equilibrium analysis}

When firms determine their optimal level of employment, unemployment and the outside options are taken as given. However, for the economy as a whole the outside options $(S)$ depend on the choices of wages and unemployment levels in all firms. Therefore, the specification of $S$ in a general equilibrium context is:

$$
S_{t}=\left(1-u_{t}\right) W^{c}+u_{t} B_{t}
$$

where $u$ is the aggregate unemployment rate, $W^{c}$ the wage rate set in other sectors and $B$ unemployment benefits. In equilibrium $W^{c}=w_{t}$. According to Blanchard and Katz (1999) and Beissinger and Egger (2004) we assume that the unemployment benefits are tied to the previous level of earned wages: ${ }^{14}$

$$
B_{t}=\rho_{t-1}\left[w_{t-1}\left(1-\tau_{t-1}^{l}+\phi_{t-1} \sigma_{t-1}\right)\right]
$$

\footnotetext{
${ }^{14}$ For more details see OECD (2003).
} 
where $\rho$ is the replacement rate. Plugging (16) into (10) taking into account (17) gives:

$$
w_{t}=f\left(\beta, \tau_{t}^{l}, \phi_{t}, \sigma_{t}, \frac{1}{\eta}, \alpha, u_{t}, w_{t-1}, \rho_{t-1}, \tau_{t-1}^{l}, \phi_{t-1}, \sigma_{t-1}\right)
$$

Furthermore, assuming the inverse relationship between $u$ and $w$ holds in $t-1$, and replacing this new aggregate wage in (11) yields:

$$
u_{t}=\digamma\left(\beta, \tau_{t}^{l}, \phi_{t}, \sigma_{t}, \frac{1}{\eta}, \alpha, u_{t-1}, \rho_{t-1}, \tau_{t-1}^{l}, \phi_{t-1}, \sigma_{t-1}, \theta_{t}, \tau_{t}^{s s f}\right)
$$

Our empirical analysis considers a linear approximation of (18) and attempts to quantify the influence of these determinants (lagged unemployment, prices, productivity and taxes) by estimating equation (19).

\section{Unemployment and taxes in the OECD countries}

\begin{tabular}{|c|c|c|c|}
\hline \multicolumn{2}{|c|}{ Variable: } & \multicolumn{2}{|l|}{ Definition and source: } \\
\hline$c$ & constant & & \\
\hline \multirow[t]{6}{*}{$u$} & unemployment rate & $=\frac{\text { Unemployed }}{\text { Labor force }}$ & {$[1]$} \\
\hline & T1100 & Taxes on income, profits and capital gains & {$[3]$} \\
\hline & $\mathrm{T} 2100$ & Soc. sec. contributions paid by employees & \\
\hline & $\mathrm{T} 2200$ & Soc. sec. contributions paid by firms & {$[3]$} \\
\hline & T3000 & Taxes on payroll and workforce & {$[3]$} \\
\hline & Labor tax base & Wages + Salaries - T2200 & {$[2][3]$} \\
\hline$\tau^{s s e}$ & payroll tax rate paid by employees & $=\frac{\mathrm{T} 2100}{\mathrm{Labor} \text { tax base }}$ & [2] [3] \\
\hline$\tau^{s s f}$ & payroll tax rate paid by firms & $=\frac{\text { Labort } 2200 \text { base }}{\text { Labor tax base }}$ & {$[2][3]$} \\
\hline$\tau^{e}$ & effective labor income tax rate & $=\frac{\text { Tidion }}{\text { Labor tax }_{\text {base }}{ }^{15}}$ & [2] [3] \\
\hline & other taxes tax rate & $=\frac{13000}{\text { Labor tax base }}$ & {$[2][3]$} \\
\hline & total wage tax rate & $=\tau^{e}+\tau^{s s e}$ & \\
\hline$\tau^{f w}$ & fiscal wedge & $=\tau^{s s e}+\tau^{s s f}+\tau^{e}+\tau^{o}$ & \\
\hline$\tau^{b}$ & payroll tax bias & $=\frac{\tau^{s s e}}{\tau^{s s f}}$ & \\
\hline$\Delta \theta$ & labor productivity growth & $=\Delta \log (\mathrm{GDP})-\Delta \log ($ employment $)$ & {$[1]$} \\
\hline$\Delta \pi$ & price inflation acceleration & $=\Delta P_{t}-\Delta P_{t-1}$ & [1] \\
\hline
\end{tabular}

\subsection{Data}

Table 1 presents the definition of the variables. The calculation of the tax rates builds up on the database of Boscá et al. (2005), but we use the methodology of Mendoza et al. (1994) to improve some technical aspects of this calculation and enlarge

\footnotetext{
${ }^{15}$ This labor tax base consists of wages and salaries, the operating surplus of unincorporated enterprises, and the property and entrepreneurial income of households.
} 
the sample to 2003 and 21 OECD countries. This methodology relates realized tax revenues (whose source is the OECD Revenue Statistics) to estimates of the associated tax bases (provided by the OECD National Accounts). It has two important advantages: (i) it allows to take into account the combined effects of statutory rates, tax deductions and tax credits; and (ii) the tax ratios estimates of different countries are easier to be compared. ${ }^{16}$

\subsection{Stylized facts}

Table 2 summarizes the main stylized facts regarding the joint evolution of unemployment, the fiscal wedge and the payroll tax bias in the 21 OECD countries for which long-time series of the relevant variables are available. According to the literature in this field we have classified them in three groups: Anglo-Saxon, continental European (EUCON from now on) and Nordic countries (including Austria, Japan and Switzerland $)^{17}$.

The first thing to draw attention on is the fact that the EUCON economies have experienced larger unemployment increases in the last four decades. The Anglo-Saxon countries had an average rise of 3 percentage points, which is approximately half the rise in the EUCON area, whereas in the Nordic countries it was also far below (3.8 when excluding Finland).

The fiscal wedge has also increased in all countries, but with a clear difference of magnitude. In the Anglo-Saxon economies the average rise amounts to 11.3 percentage points, even though they display a strong heterogeneity (Canada and Ireland almost 20, in contrast with UK below 5). The average rise in the EUCON countries is somewhat above 20 percentage points with no sharp within differences (except in the Netherlands). In the Nordic ones there is a diverse experience, with Finland and Sweden above 30 and Denmark and Norway below 20. The seventh column of figure 2 completes this information with the proportion of the fiscal wedge increase due to the rise in payroll taxes: $\frac{\Delta\left(\tau^{s s e}+\tau^{s s f}\right)}{\Delta \tau^{f w}}$. Excluding Denmark, this rise explains a substantial part of the fiscal wage increase in the OECD countries, which is sizeable (in proportion and absolute values) in the Nordic countries -Sweden (24.9 out of 33.4 percentage points), Finland (23.6 out of 32.0 ) and Norway (15.9 out of 15.4)-, but also in some EUCON countries such as Greece (20.5 out of 25.2), Portugal (18.5 out of 25.3), Spain (16.6 out of 24.6) or Germany (14.0 out of 14.4). The contrast with the Anglo-Saxon countries is apparent.

\footnotetext{
${ }^{16}$ Carey and Tchilinguirian (2000) and Volkerink and De Haan (2001) discuss this methodology and suggest some refinements to obtain more realistic tax ratios. A detailed account of its advantages is provided by the latter (p. 11).

${ }^{17}$ It is well-known that Austria has a centralized bargaining system and belongs to the Nordic area. The same happens with Japan and Switzerland which have strong wage coordination (via arbitration committees in the first case and via the 'spring offensive' in the second). See Soskice (1990) for details.
} 
With respect to the $\mathrm{PTB}, \tau^{b}$, it is important to note that a neutral distribution between employees and firms corresponds to 100. In all the OECD economies $\tau^{b}$ is below 100 both in 1965 and 2003 indicating that there is a bias towards firms (with few exceptions among which the Netherlands and Denmark). The last column indicates to what extent the rise in the incidence of payroll taxes has been accompanied by a change in their composition. The clearest picture emerges from the Nordic countries, all having increased the proportion paid by employees except Austria. This is also the case in most of the EUCON countries, in particular the core of the continental Europe in contrast with the southern periphery (Greece, Portugal and Spain).

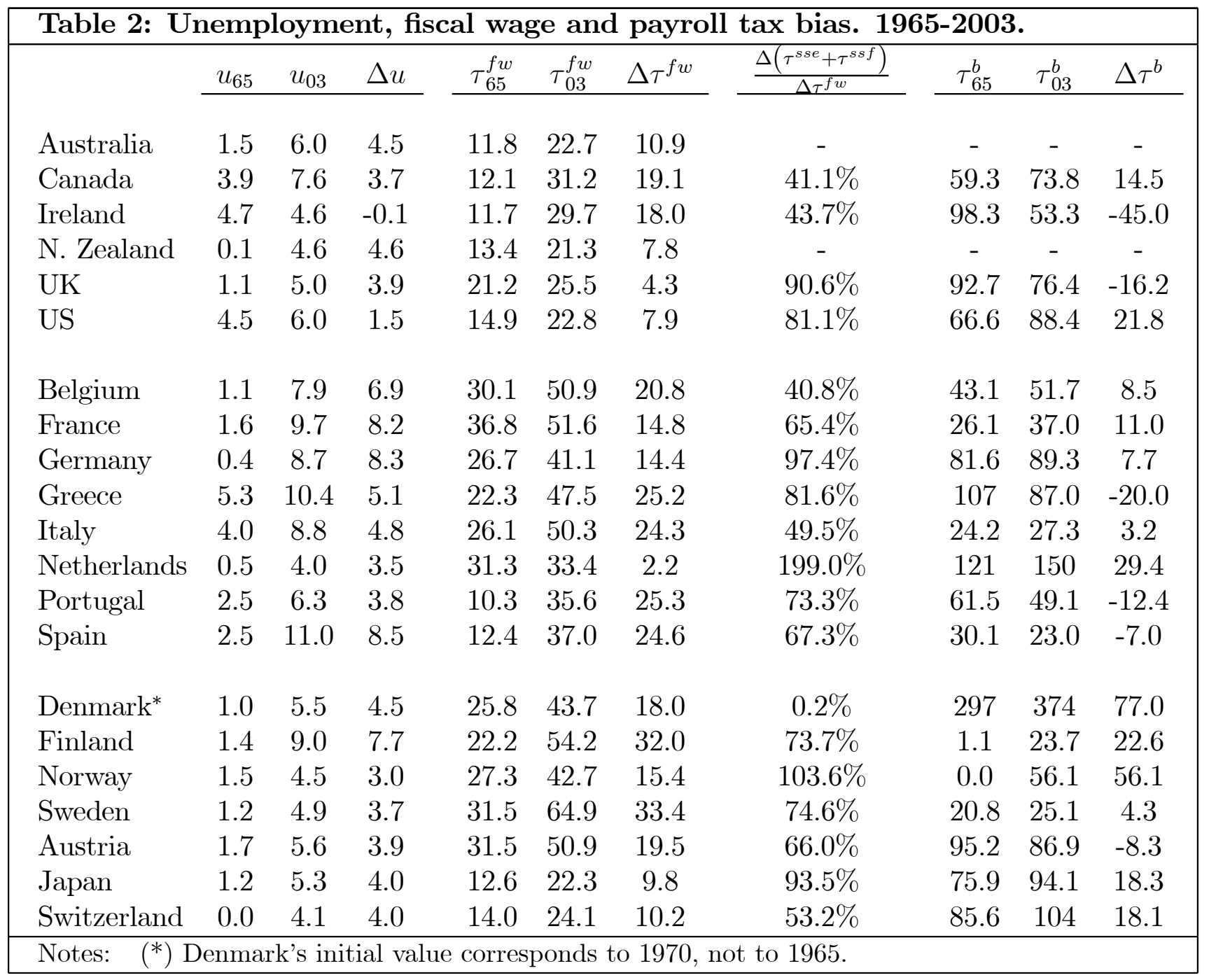

These data may also be used to examine to what extent would it be possible to consider a relationship between unemployment and the fiscal wedge or the PTB across the OECD countries. When the change in unemployment (column $\Delta u$ in figure 2) is examined together with the changes in the fiscal wedge (column $\Delta \tau^{f w}$ ) a mild positive relationship can be identified, but the correlation coefficient only attains 0.28 (which reduces to 0.21 when the EMU countries are considered). ${ }^{18}$ On the contrary, there is

\footnotetext{
${ }^{18}$ As noted, the presentation of the information in tables 2 to 5 is organized according to the standard
} 
a sharp contrast between the EMU and the rest of the OECD countries when it turns to the relationship between unemployment and PTB changes. This is shown in figure 1. When all economies are considered (figure 1a) the coefficient of correlation is 0.09 and there is not much to be said, except that it is interesting to observe that most of the Nordic and Anglo-Saxon countries appear in the upper side of the regression line, in sharp contrast to the ones in the EMU. When only the EMU countries are taken into account, figure 1b, the picture shows a clear-cut positive relationship between both variables with a correlation coefficient of 0.58 . Note, however, that Netherlands appears as an outlier. This is important because, in the absence of this country, this value rises to 0.82 and reinforces this relationship. This is a first important insight from considering not only the level effect of the fiscal wedge, but also the payroll tax composition.

Figure 1. Unemployment and the payroll tax bias. 1965-2003.
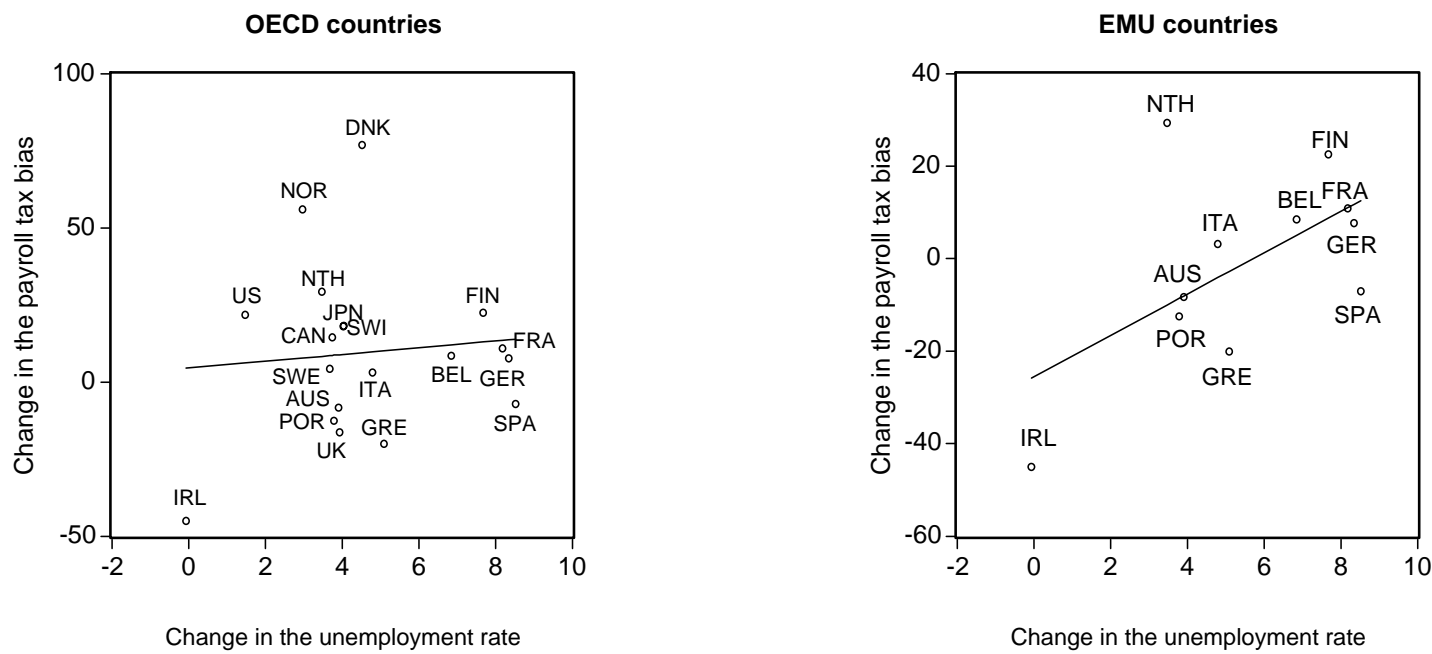

\section{Empirical analysis}

Given the economic insights provided by the theoretical model and the economic facts just reviewed, in this section we endeavor the precise estimation of the unemployment effects of the fiscal wedge and the PTB for each of the 21 OECD countries considered.

classification of countries in the literature. Nevertheless, in terms of the outcome of our analysis, in figures 1 and 2 we find it advantageous to refer to the EMU countries (EUCON plus Austria, Finland and Ireland). See Section 4.2 for further details. 


\subsection{A simple reduced-form unemployment equation}

A correct estimation of the above mentioned effects requires to control for all other potentially significant determinants. Here we face an important trade-off between accuracy and comparability. If we wanted to be fully precise we would attempt the estimation of specific individual models for each of the 21 countries. This is not the purpose of our analysis, which seeks to compare the effects of the tax structure under the same analytical benchmark. Therefore, even at the cost of increasing the error terms, we restrict the pool of explanatory variables such that it is common to the 21 economies considered. Even if comparability has become a priority in the literature, it is important to note that our analysis is much less restrictive than it is common. In particular, it has become standard to take 5-years averages and increase the number of degrees of freedom by enlarging the amount of cross-section units. ${ }^{19}$ In this context, the use of panel data estimation techniques is highly restrictive in terms of individual (country) results. Our methodology differs crucially from this strategy: it uses long time-series to conduct country-specific regressions and only restricts the pool of explanatory variables. In other words, given this pool of variables: (i) all countries differ in all the estimated coefficients; and (ii) every country is considered on its own so that the appropriate lag structure is estimated.

Albeit circumscribing the explanatory variables to a common pool, we attempt to partially overcome this restriction by taking into account productivity growth as a proxy for the supply-side determinants of unemployment and inflation acceleration as a proxy of demand-side pressures. This is thus our way-out to control for other potential determinants of unemployment beyond lagged unemployment, the fiscal wedge and the PTB. The concrete specification of the reduced-form unemployment equation is:

$u_{i t}=\alpha_{1 i}+\alpha_{2 i j} \sum_{j=1}^{n} u_{i t-j}+\alpha_{3 i j} \sum_{j=1}^{n} \tau_{i t-j}^{f w}+\alpha_{4 i j} \sum_{j=1}^{n} \tau_{i t-j}^{b}+\alpha_{5 i j} \sum_{j=1}^{n} \Delta \theta_{i t-j}+\alpha_{6 i j} \sum_{j=1}^{n} \Delta \pi_{i t-j}+\varepsilon_{t}$,

where $\alpha_{i}$ are the constants, $i=1, \ldots 21$ are the 21 economies considered, and $j=1, \ldots n$ is the lagged structure of the rest of the explanatory variables. Because all the variables considered are either rates or growth rates, we treat them as $I(0)$ and we do not apply cointegration techniques; furthermore, since we do not estimate multi-equation models we use OLS and not instrumental variables methods such as 2SLS or 3SLS.

Tables 3 to 5 display the results for the 21 individual regressions. The estimated coefficients are presented first, then the $R^{2}$, the standard error of the regression and finally the results of a Lagrange Multiplier serial correlation test. The reason for showing the absence of serial correlation is that this is a necessary condition for the other

\footnotetext{
${ }^{19}$ See Blanchard and Wolfers (2000) or Nickell et al. (2005).
} 
misspecification tests to hold. We have indeed conducted these tests (heteroskedasticity, linearity, ...) as well as structural stability tests (such as the Cusum and the Cusum² tests). ${ }^{20}$ The final form of each estimated equation is well specified and the estimated coefficients structurally stable.

With respect to the Anglo-Saxon countries, the tax structure does not seem to play a significant role in explaining the trajectory of unemployment. The fiscal wedge is significant in Canada and New Zealand, would be significant only at 30\% in Australia and Ireland, is totally non-significant in the UK and displays the wrong sign in the US. With respect to the PTB, the results are even worse: it is only significant in Canada (with a negative sign) and the US (at $10 \%$ with a positive sign). ${ }^{21}$ On the contrary, productivity growth and inflation acceleration are significant and correctly signed in all cases with the exception of Ireland. ${ }^{22}$

\section{Table 3: Unemployment equation. Anglo-Saxon countries.}

Dependent variable: $u_{t}$.

\begin{tabular}{|c|c|c|c|c|c|c|c|c|c|c|c|c|c|}
\hline & $c$ & $u_{t-1}$ & $\Delta u_{t-1}$ & $\Delta u_{t-2}$ & $\tau_{t}^{f w}$ & $\Delta \tau_{t}^{f w}$ & $\tau_{t}^{b}$ & $\Delta \theta_{t}$ & $\Delta \theta_{t-1}$ & $\Delta \pi_{t}$ & $R^{2}$ & s.e. & $S C$ \\
\hline Aust. & $\begin{array}{l}0.40 \\
(0.89)\end{array}$ & $\begin{array}{l}0.80 \\
(0.09)\end{array}$ & $\begin{array}{l}0.37 \\
(0.24)\end{array}$ & & $\begin{array}{l}0.06 \\
(0.07)\end{array}$ & & & $\begin{array}{c}-0.17 \\
(0.09)\end{array}$ & & $\begin{array}{c}-0.19 \\
(0.07)\end{array}$ & 0.922 & 0.81 & $\begin{array}{l}0.49 \\
{[0.48]}\end{array}$ \\
\hline Can. & $\begin{array}{l}4.48 \\
(2.22)\end{array}$ & $\begin{array}{l}0.52 \\
(0.13)\end{array}$ & $\begin{array}{l}0.40 \\
(0.12)\end{array}$ & $\begin{array}{l}0.25 \\
(0.10)\end{array}$ & $\begin{array}{l}0.11 \\
(0.03)\end{array}$ & & $\begin{array}{c}-0.05 \\
(0.03)\end{array}$ & $\begin{array}{c}-0.15 \\
(0.06)\end{array}$ & & $\begin{array}{c}-0.22 \\
(0.05)\end{array}$ & 0.935 & 0.64 & $\begin{array}{l}0.01 \\
{[0.92]}\end{array}$ \\
\hline Ire.* & $\begin{array}{l}0.05 \\
(4.72)\end{array}$ & $\begin{array}{l}0.80 \\
(0.10)\end{array}$ & $\begin{array}{l}0.25 \\
(0.16)\end{array}$ & $\begin{array}{l}0.33 \\
(0.14)\end{array}$ & $\begin{array}{l}0.06 \\
(0.09)\end{array}$ & & $\begin{array}{l}0.02 \\
(0.04)\end{array}$ & & $\begin{array}{c}-0.20 \\
(0.12)\end{array}$ & $\begin{array}{c}-0.12 \\
(0.07)\end{array}$ & 0.910 & 1.52 & $\begin{array}{l}2.65 \\
{[0.10]}\end{array}$ \\
\hline N. Z. & $\begin{array}{c}-0.71 \\
(0.57)\end{array}$ & $\begin{array}{l}0.89 \\
(0.04)\end{array}$ & $\begin{array}{l}0.35 \\
(0.15)\end{array}$ & & $\begin{array}{l}0.06 \\
(0.03)\end{array}$ & $\begin{array}{c}-0.12 \\
(0.11)\end{array}$ & & $\begin{array}{c}-0.10 \\
(0.07)\end{array}$ & & $\begin{array}{c}-0.06 \\
(0.03)\end{array}$ & 0.954 & 0.74 & $\begin{array}{l}1.72 \\
{[0.19]}\end{array}$ \\
\hline UK & $\begin{array}{l}2.88 \\
(2.77)\end{array}$ & $\begin{array}{l}0.89 \\
(0.03)\end{array}$ & $\begin{array}{l}0.91 \\
(0.12)\end{array}$ & & $\begin{array}{c}-0.05 \\
(0.07)\end{array}$ & & $\begin{array}{l}0.003 \\
(0.011)\end{array}$ & $\begin{array}{c}-0.24 \\
(0.08)\end{array}$ & $\begin{array}{c}-0.26 \\
(0.06)\end{array}$ & $\begin{array}{c}-0.01 \\
(0.02)\end{array}$ & 0.967 & 0.65 & $\begin{array}{l}0.02 \\
{[0.90]}\end{array}$ \\
\hline US & $\begin{array}{c}-0.62 \\
(2.54)\end{array}$ & $\begin{array}{l}0.83 \\
(0.09)\end{array}$ & & & $\begin{array}{c}-0.12 \\
(0.07)\end{array}$ & & $\begin{array}{l}0.065 \\
(0.040)\end{array}$ & $\begin{array}{c}-0.27 \\
(0.11)\end{array}$ & $\begin{array}{c}-0.38 \\
(0.10)\end{array}$ & $\begin{array}{c}-0.28 \\
(0.18)\end{array}$ & 0.863 & 0.62 & $\begin{array}{l}2.96 \\
{[0.09]}\end{array}$ \\
\hline
\end{tabular}

Notes: $\quad$ standard errors in parentheses; s.e. $=$ standard error of regression.

(*) Inflation acceleration in Ireland is lagged once.

SC: Serial Correlation LM test with probabilities in brackets; $5 \%$ critical value: $\chi^{2}(1)=3.84$.

The EUCON countries is the group were the tax structure plays, generally, a significant role in explaining unemployment. There are, however, some exceptions like Germany, where the fiscal wedge is not significant (but the PTB is fully significant) or Greece, where the PTB is not significant (the fiscal wedge at 16\%). Productivity growth and inflation acceleration are also generally significant (and negatively signed, as expected), still with some exceptions like the latter in Spain or the former in Portugal.

One important finding for this group of countries is that the PTB seems to work better than the fiscal wedge. In all countries the sign is positive indicating that the higher the proportion of payroll taxes paid by employees the higher unemployment.

\footnotetext{
${ }^{20}$ We do not report them for the sake of brevity.

${ }^{21}$ In Australia and New Zealand there is no PTB due the absence of payroll taxes.

${ }^{22}$ In fact, none of the explanatory variables in this country (except the lags of the dependent variable) are fully significant. This is the reason why this is the only country where the fitted values would, on average, diverge from the actual values by more than 1.5 percentage points.
} 
This is consistent with the stylized facts presented above according to which the EMU countries are the ones where there is a close positive relationship between unemployment changes and PTB changes in the last decades. Moreover, recall that this new result has been rationalized in Section 2 by means of a ratio of the unemployment elasticities with respect to the payroll taxes levied on workers and firms $(\xi)$ that is larger than one.

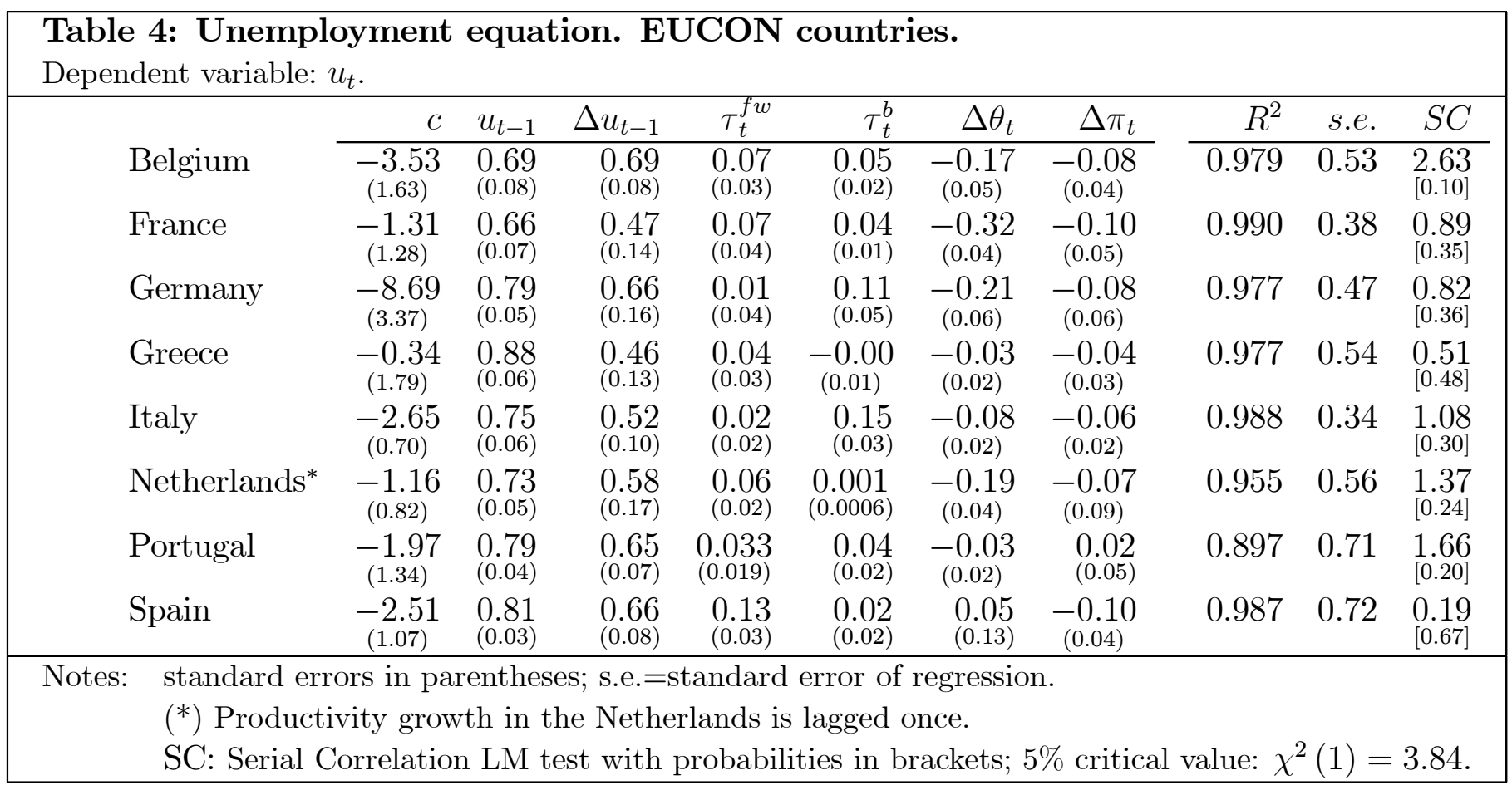

\begin{tabular}{|c|c|c|c|c|c|c|c|c|c|c|c|}
\hline \multicolumn{12}{|c|}{$\begin{array}{l}\text { Table 5: Unemployment equation. Nordic countries. } \\
\text { Dependent variable: } u_{t} \text {. }\end{array}$} \\
\hline & $c$ & $u_{t-1}$ & $\Delta u_{t-1}$ & $\tau_{t}^{f w}$ & $\tau_{t}^{b}$ & $\Delta \theta_{\tau}$ & $\Delta \pi_{t}$ & $\Delta \pi_{t-1}$ & $R^{2}$ & s.e. & $S C$ \\
\hline Denmark & $\begin{array}{l}0.79 \\
(1.80)\end{array}$ & $\begin{array}{l}0.86 \\
(0.07)\end{array}$ & $\begin{array}{l}0.63 \\
(0.24)\end{array}$ & $\begin{array}{l}0.01 \\
(0.06)\end{array}$ & $\begin{array}{c}-0.00 \\
(0.002)\end{array}$ & $\begin{array}{c}-0.18 \\
(0.12)\end{array}$ & $\begin{array}{l}0.13 \\
(0.13)\end{array}$ & & 0.869 & 0.83 & $\begin{array}{l}0.10 \\
{[0.75]}\end{array}$ \\
\hline Finland & $\begin{array}{c}-0.34 \\
(1.08)\end{array}$ & $\begin{array}{l}0.76 \\
(0.07)\end{array}$ & $\begin{array}{l}0.86 \\
(0.17)\end{array}$ & $\begin{array}{l}0.08 \\
(0.03)\end{array}$ & $\begin{array}{c}-0.04 \\
(0.02)\end{array}$ & $\begin{array}{c}-0.29 \\
(0.13)\end{array}$ & $\begin{array}{c}-0.06 \\
(0.04)\end{array}$ & $\begin{array}{c}-0.05 \\
(0.03)\end{array}$ & 0.968 & 0.87 & $\begin{array}{l}0.08 \\
{[0.89]}\end{array}$ \\
\hline Norway & $\begin{array}{c}-0.01 \\
(0.95)\end{array}$ & $\begin{array}{l}0.87 \\
(0.09)\end{array}$ & $\begin{array}{l}0.48 \\
(0.15)\end{array}$ & $\begin{array}{l}0.01 \\
(0.02)\end{array}$ & $\begin{array}{l}0.00 \\
(0.01)\end{array}$ & $\begin{array}{c}-0.08 \\
(0.06)\end{array}$ & $\begin{array}{l}0.00 \\
(0.01)\end{array}$ & & 0.921 & 0.45 & $\begin{array}{l}0.00 \\
{[0.99]}\end{array}$ \\
\hline Sweden & $\begin{array}{c}-0.31 \\
(0.71)\end{array}$ & $\begin{array}{l}0.81 \\
(0.11)\end{array}$ & $\begin{array}{l}0.76 \\
(0.28)\end{array}$ & $\begin{array}{l}0.02 \\
(0.02)\end{array}$ & $\begin{array}{l}0.02 \\
(0.02)\end{array}$ & $\begin{array}{c}-0.09 \\
(0.07)\end{array}$ & $\begin{array}{c}-0.04 \\
(0.04)\end{array}$ & & 0.916 & 0.68 & $\begin{array}{l}0.39 \\
{[0.53]}\end{array}$ \\
\hline Austria & $\begin{array}{c}-2.55 \\
(1.97)\end{array}$ & $\begin{array}{l}0.84 \\
(0.10)\end{array}$ & $\begin{array}{l}0.33 \\
(0.16)\end{array}$ & $\begin{array}{l}0.04 \\
(0.03)\end{array}$ & $\begin{array}{c}0.02 \\
(0.015)\end{array}$ & $\begin{array}{c}-0.09 \\
(0.03)\end{array}$ & $\begin{array}{c}-0.09 \\
(0.05)\end{array}$ & & 0.979 & 0.28 & $\begin{array}{l}3.07 \\
{[0.08]}\end{array}$ \\
\hline Japan* & $\begin{array}{c}-0.07 \\
(0.67)\end{array}$ & $\begin{array}{l}0.95 \\
(0.05)\end{array}$ & $\begin{array}{l}0.30 \\
(0.13)\end{array}$ & $\begin{array}{c}-0.01 \\
(0.01)\end{array}$ & $\begin{array}{l}0.01 \\
(0.01)\end{array}$ & $\begin{array}{c}-0.05 \\
(0.02)\end{array}$ & $\begin{array}{c}-0.03 \\
(0.003)\end{array}$ & & 0.982 & 0.17 & $\begin{array}{l}0.05 \\
{[0.83]}\end{array}$ \\
\hline Switzerland & $\begin{array}{r}1.58 \\
(2.29) \\
\end{array}$ & $\begin{array}{l}0.92 \\
(0.08) \\
\end{array}$ & $\begin{array}{l}0.78 \\
(0.12) \\
\end{array}$ & $\begin{array}{c}-0.07 \\
(0.03)\end{array}$ & $\begin{array}{c}-0.00 \\
(0.03)\end{array}$ & $\begin{array}{c}-0.15 \\
(0.05)\end{array}$ & & $\begin{array}{c}-0.05 \\
(0.03)\end{array}$ & 0.972 & 0.28 & $\begin{array}{l}0.30 \\
{[0.58]}\end{array}$ \\
\hline \multicolumn{12}{|c|}{$\begin{array}{ll}\text { Notes: } & \text { standard errors in parentheses; s.e.=standard error of regression. } \\
& (*) \Delta u_{t-2} \text { also enters the specification of Switzerland, with coefficient }-0.38(0.13) \text {. } \\
& \text { SC: Serial Correlation LM test with probabilities in brackets; } 5 \% \text { critical value: } \chi^{2}(1)=3.84 \text {. }\end{array}$} \\
\hline
\end{tabular}

Finally, in the Nordic area we do not find a correct and significant influence of the tax structure on unemployment. The only economy where the fiscal wedge and the PTB are significant is Finland, which is generally considered the less Nordic of the Nordic 
countries in terms of wage bargaining. Austria seems also to be close to the EUCON area -the fiscal wedge and the PTB are correctly signed and would be significant at 20\%- whereas in Sweden both would be significant only at $30 \%$, like the PTB in Japan. In short, no clean pattern can be identified.

\subsection{Unemployment persistence}

One of the contributions of our country-individual analysis is the possibility of evaluating if there is a relationship between unemployment persistence and the influence of the exogenous variables we are considering. The natural group of countries where to perform this evaluation are the EMU countries for various reasons. First, it is feasible, since it includes a large enough amount of countries. ${ }^{23}$ Second, the fiscal policies of all these economies are tied by the Stability and Growth Pact seeking to bring deficits close to balance. In this context, knowledge on the unemployment consequences of changes in the tax composition is extremely valuable in this area. Third, unemployment persistence has been (and is still) considered one of the crucial features of their labor markets. ${ }^{24}$

Departing from the information obtained in the previous section, figure 2 relates the persistence coefficients of the EMU countries with the long-run elasticities of the exogenous variables. Several outcomes from this analysis are worth noting. First, there seems to be a mild positive relationship between unemployment persistence and the fiscal wedge with the correlation coefficient of these two series placed at 0.31 (even in the absence of Spain it would reach 0.25 ). Second, given the fiscal wedge (the level effect of the tax system), the PTB (the composition effect) cannot be related with the degree of persistence in unemployment: the correlation coefficient in this case is 0.09 (which would be null in the absence of Germany). Third, the impact of inflation acceleration is lower the higher is unemployment persistence: the correlation coefficient amounts to -0.60 and indicates that the higher is unemployment sluggishness the smaller we should expect to be the impact of demand-side shocks (even if their effects are more persistent). Finally, as shown in figure $2 \mathrm{~d}$, there is also a clear-cut positive relationship between unemployment persistence and productivity growth: the coefficient of correlation is 0.44 and indicates that countries where unemployment is more sticky tend to take greater advantage of increases in productivity growth.

Taking a step forward, the overall picture suggests that the strength of the institutional and supply-side determinants is positively related with unemployment persis-

\footnotetext{
${ }^{23}$ For the other areas it is not feasible, whereas we have all the EMU countries except Luxembourg. To provide the clearest picture when the sign of one coefficient is not correct the corresponding country is not considered (Greece in figure 1b, Portugal and Ireland in 1c and Spain in 1d).

${ }^{24}$ For an analysis relating fiscal policies and the labor market outcomes of Europe and the US see Raurich, Sala and Sorolla (2006).
} 
tence. On the contrary, our results point to a reduced impact of demand-side variables (captured via inflation acceleration) the higher this persistence.

Figure 2. Unemployment persistence and key variables in the EMU countries

a. Fiscal wedge

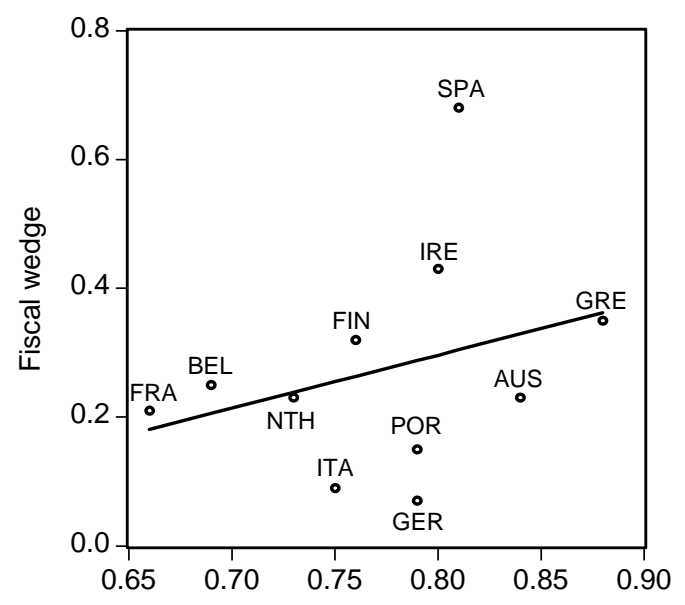

Unemployment persistence

c. Inflation acceleration

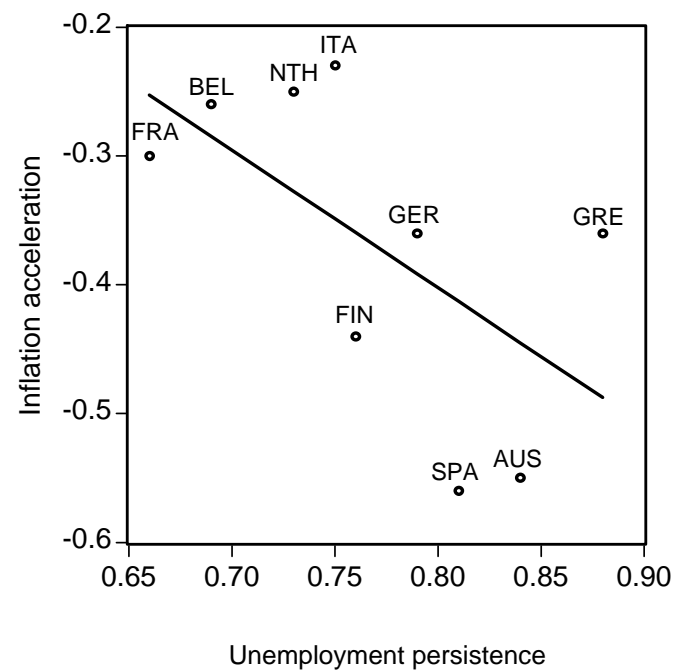

b. Payroll tax bias
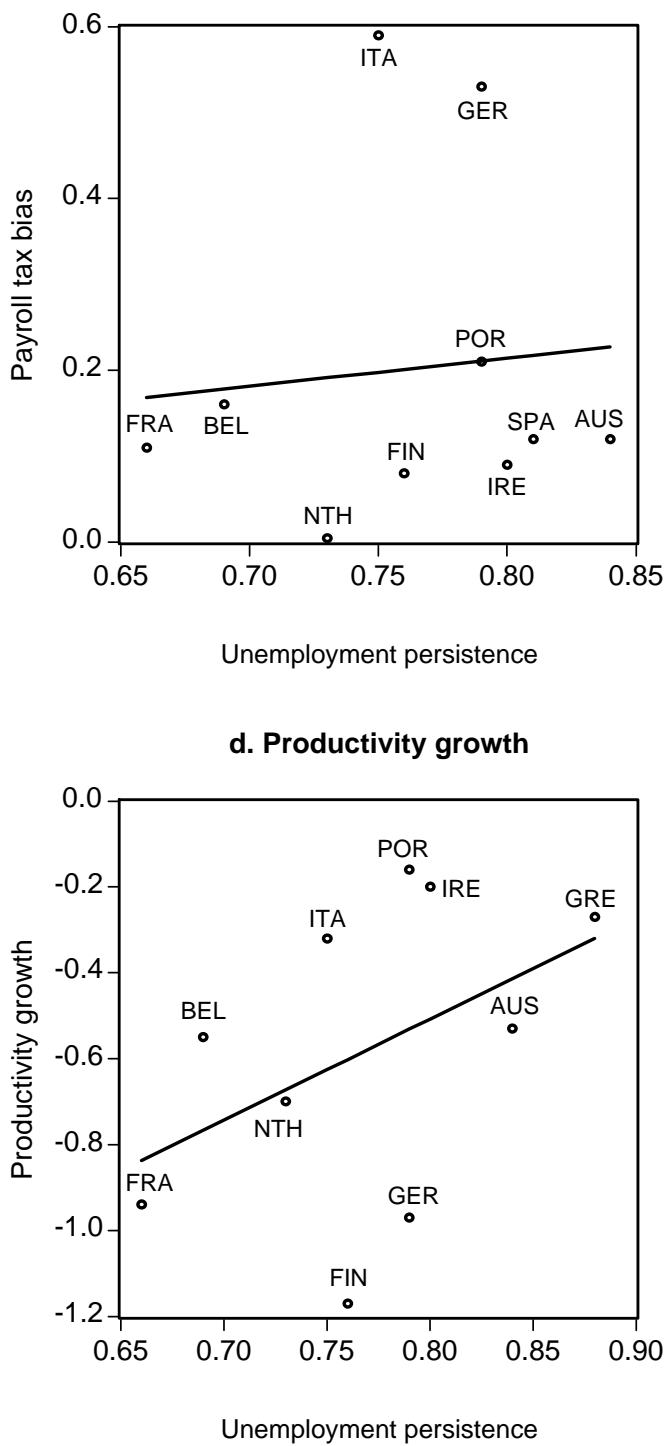

\section{Conclusions}

This paper examines the incidence of the tax structure on unemployment in the OECD countries. It does so by means of a right-to-manage model that encompasses different wage bargaining systems and allows an evaluation of the effects of different taxes. 
We think of this model as to provide an adequate benchmark to conduct our empirical analysis. We do not seek an exact empirical replica; our target is to provide a stylized picture of the economic relationships at work for a wide group of countries. In particular, we take a country-specific perspective and investigate to what extent the fiscal wedge (as institutional variable), inflation acceleration (aimed to proxy demandside influences) and productivity growth (aimed to proxy supply-side influences) are able to explain the diverse unemployment experiences of the OECD countries. In undertaking this analysis we face a hard trade-off between accuracy and comparability. We favor the latter, but in a complete different way than in the standard literature. In particular, instead of focusing on a cross-section analysis (augmented with some time-series data points), we estimate stylized country-specific reduced-form dynamic unemployment equations. Comparability requires to restrict the potential pool of explanatory variables, but individual estimation allows us to be precise. Furthermore, the explanatory variables we use are available for a long period of time and we can conduct a time-series analysis without being forced to pool the data. In this way, the paper contributes to the field in a number of dimensions previously disregarded (the analysis is country-specific and considers dynamics) and yields new empirical evidence.

The first important result is the confirmation that the fiscal wedge in the AngloSaxon and Nordic areas does not play a prominent role in explaining the unemployment trajectory. On the contrary, we find a significant influence in the EUCON countries. Our model is able to rationalize these results by encompassing the specificities of these three areas: union power in continental Europe is higher (relative to the Anglo-Saxon countries) and there is no full centralization of collective bargaining (like in the Nordic economies); therefore, the more payroll taxes are paid by the workforce, the more this is translated into wage increases thereby pushing unemployment upwards.

The novelty of our findings is that we identify a particular feature of the EUCON countries: not only the level of the fiscal wedge matters, but also the composition of this wedge. In particular, the more payroll taxes are biased towards the employees (and the lower towards the firm) the higher unemployment. Our model explains this result via the ratio of the unemployment elasticities with respect to the payroll taxes levied on workers and firms, $\xi$. When these two components of the payroll tax rise alike (so that the effective labor income tax, $\tau^{e}$, remains constant) it follows that $\xi>1$. That is, the elasticity of the imposition levied on workers is higher than the one levied on firms and changes in these components will affect unemployment even when the overall fiscal wedge stays unchanged. This explains why the PTB has a significant influence in countries with public transfers that (i) are not clearly perceived by the employees and (ii) are not taken into account in wage bargaining. These two situations correspond to the Anglo-Saxon area, where these transfers are small, and to the Nordic area, where the 
internalization of public transfers is large (this is measured by $\phi$ and allows to associate the situation where $\phi=1$ with the Nordic scenario where the tax composition does not play any relevant role).

The fact that the elasticity of the imposition on workers is larger than the one on firms is central to our analysis and can be rationalized as follows. The higher the workers' share in the payroll tax, $\tau^{s s e}$, the higher their gross wage claims for a given rise in net wages. That is, higher imposition is shifted towards higher labor costs via the wage bargaining process thereby reducing the firm's labor demand and increasing unemployment. The effect of a rise in payroll taxes is larger if it affects the workers' component (in which case the labor cost rises by $\frac{1}{\left(1-\tau^{s s e}\right)}$ ) rather than the firms' component (in which case the labor cost is multiplied by $1+\tau^{s s f}$ ). Note that, in contrast to $\tau^{s s e}$, any raise in $\tau^{s s f}$ increases the labor cost proportionally with smaller unemployment consequences.

The second set of salient findings is the following. The fiscal wedge seems to display a positive relationship with unemployment persistence according to which those countries with higher stickiness in unemployment would have to face worse effects from the fiscal wedge. In terms of economic policy this implies that, other things equal, these countries would have more incentives to cut taxes than countries with less unemployment persistence. This does not apply to the payroll tax bias which, despite having a positive impact on unemployment, does not show any relationship with the degree of persistence in unemployment. We find this result sensible because firms tend to translate their payroll tax component to lower hirings. Since this is a one-sided decision taken by firm, we should not expect a relationship with unemployment persistence. Rather, we would have to investigate the consequences of this translation in terms of labor-capital substitution and its implications for the production function. If changes in the tax composition that leave the overall amount of revenues unchanged are harmless in terms of unemployment persistence, new possibilities for policy makers can be considered.

Additionally we find the strength of institutions (the fiscal wedge) and supply-side determinants (productivity growth) in shaping the unemployment path to be positively related with unemployment persistence and, conversely, the strength of the demandside elements (inflation acceleration) to display a negative relationship. This suggests that situations of high unemployment persistence may tend to require more structural reforms; then, as persistence tends to decline, a mixture of supply-side and demandmanagement policies would seem an appropriate strategy to ensure the full-benefits of supply-side reforms and the promotion of economic growth. This of course, applies to economic areas such as the EMU that has been characterized for years by its unemployment persistence; our results are less relevant to the Anglo-Saxon and Nordic 
economies traditionally much quicker in adapting their labor markets to the rapidly changing conditions of today's economies.

Notwithstanding the virtues of this country-individual analysis, we have just offered a stylized view of the impact of central driving forces on unemployment (institutional, demand-side and supply-side). These results and their policy implications should thus be taken with caution and much more effort needs to be devoted to the understanding of these relationships in each of the analyzed countries. One immediate extension should be the estimation of multi-equation systems considering labor demand and labor supply curves so that the wage elasticity of these two curves is considered together with the corresponding cross-equation feedback effects. This would allow a better understanding of the economic relations at work.

\section{References}

[1] Alesina, A. and R. Perotti (1997). "The Welfare Sate and Competitiveness", The American Economic Review. 87 (5): 921-939.

[2] Beissinger, T. and H. Egger (2004). "Dynamic Wage Bargaining if Benefits are Tied to Individual Wages", Oxford Economics Papers. 56: 437-460.

[3] Belot, M. and J.C. Van Ours (2004). "Does the Recent Success of Some OECD Countries in Lowering their Unemployment Rates Lie in the Clever Design of their Labour Market Reforms?" Oxford Economic Papers. 56 (4): 621-642

[4] Blanchard, O. (2006). "European Unemployment: the Evolution of facts and ideas". Economic Policy. 21 (45): 5-59.

[5] Blanchard, O. and L. Katz (1999). "Wage Dynamics: Reconciling Theory and Evidence", American Economic Review, Papers and Proceedings. 89: 69-74.

[6] Blanchard, O. and J. Wolfers (2000). "The Role of Shocks and Institutions in the Rise of European Unemployment: The Aggregate Evidence", The Economic Journal. 110: C1-C33.

[7] Boscá, J., J.R. García and D. Taguas (2005). "Tipos Efectivos de Gravamen y Convergencia Fiscal en la OCDE: 1965-2001". Hacienda Pública Española. 174: 119-141.

[8] Booth, A. (1995). The Economics of the Trade Unions. Cambridge, U.K.: Cambridge University Press.

[9] Carey, D. and H. Tchilinguirian (2000). "Average Effective Tax Rates on Capital, Labour and Consumption". Working Paper 258: Economics Departament, OECD.

[10] Daveri, F. and G. Tabellini (2000). "Unemployment, Growth and Taxation in Industrial Countries", Economic Policy. 15 (30): 49-104. 
[11] Doménech, R. and J.R. García (2006). "Unemployment, Taxation and Public Expenditure in a Growing Economy". Mimeo. University of Valencia.

[12] Elmeskov, J., J. Martin and S. Scarpetta (1998). "Key lessons for labour market reforms: Evidence from OECD countries' experience", Swedish Economic Policy Review. 5 (2): 205-252.

[13] Farber, H. (1986). "The Analysis of Union Behavior" in: O. Ashenfelter and R. Layard (eds), Handbook of Labor Economics. Amsterdam: Elservier Science/North-Holland. 2: 1139-1189.

[14] Gruber, J. (1997). "The Incidence of Payroll Taxation: Evicence from Chile". Journal of Labor Economics. 15 (3): s72-s101.

[15] Koskela, E. and R. Schöb (1999). "Does the Composition of Wage and Payroll Taxes matter Under Nash Bargaining?", Economics Letters. 64: 343-349.

[16] Layard, P., S. Nickell and R. Jackman (1991). Unemployment-Macroeconomics Performance and the Labour Market, Oxford University Press, Oxford.

[17] Manning, A. (1990). "Imperfect Competition, Multiple Equilibria and Unemployment Policy", The Economic Journal. 100: 151-162.

[18] Mendoza, E., A. Razin and L. Tesar (1994). "Effective Tax Rates in Macroeconomic Cross-Country Estimates of Tax Rates on Factor Incomes and Consumption", Journal of Monetary Economics. 34 (3): 297-324.

[19] Muysken, J. and A.P. van Veen (1996). "It does matter which side of the labour market is taxed" in: C. Kool, J. Muysken and A.P. van Veen (eds.), Essays on Money, Banking and Regulation, Kluwer Publishers, Boston: 223-248.

[20] Muysken J., T. Van Veen and E. De Regt (1999). "Does a Shift in the Tax Burden Create Employment?". Applied Economics. 31: 1195-1205.

[21] Nickell, S. (1982). "Wage and Unemployment: A General Framework", The Economic Journal. 92 (365): 51-55.

[22] Nickell, S. and Andrews, M. (1983): "Unions, Real Wages and Employment in Britain 1951-79", Oxford Economic Papers. 35: 183-206.

[23] Nickell, S. (1997). "Unemployment and labour Market Rigidities: Europe versus North America". Journal of Economic Perspectives. 11 (3): 55-74.

[24] Nickell, S. and R. Layard (1999). "Labour Market Institutions and Economic Performance" in: O. Ashenfelter and D. Card (eds.), Handbook of Labor Economics: North Holland, Amsterdam: 3.

[25] Nickell, S., L. Nunziata and W. Ochel (2005). "Unemployment in the OECD since the 1960s. What do we know?". The Economic Journal. 115: 1-27.

[26] OECD (2004). National Accounts. Paris, OECD.

[27] OECD (2004). Revenue Statistics of OECD Member Countries. Paris, OECD. 
[28] OECD(2003). Benefits and Wages Outlook indicators 2002. Paris, OECD.

[29] Oswald, A.J. (1985). "The Economic Theory of Trade Unions: An introductory Survey", Scandinavian Journal of Economics. 87 (2): 160-193

[30] Picard, P. and E. Toulemonde (2001). "On the Equivalence of Taxes Paid by Employers and Employees", Scottish Journal of Political Economy. 48 (4): 461-470.

[31] Pissarides C.A.(1998). "The Impact of Employment Tax Cuts on Unemployment and Wages: The Role of Unemployment Benefits and Tax Structure". European Economic Review. 42: 155-183.

[32] Rasmussen, S. (1997). "Non-Equivalence of Employment and Payroll Taxes in Imperfectly Competitive Labour Markets", Working Paper 1997-22: Department of Economics, University of Aarhus.

[33] Raurich, X., H. Sala and V. Sorolla (2006). "Unemployment, Growth and Fiscal Policy: New Insights on the Hysteresis Hypotheses", Macroeconomic Dynamics. 10 (3): 285-316.

[34] Soskice, D. (1990). "Wage determination: The changing role of institutions in advanced industrialized countries", Oxford Review of Economic Policy. 6: 36-61.

[35] Summers, L. (1989): "Some Simple Economics of Mandated Benefits", The American Economic Review. 79: 177-86.

[36] Summers, L., J. Gruber and R. Vergara (1993). "Taxation and the Structure of Labor Markets", Quarterly Journal of Economics. 108 (2): 385-411.

[37] Volkerink, B. and J. De Haan (2001). "Tax Ratios:A Critical Survey", OECD Tax Policy Studies. $\mathbf{5}$. 


\section{APPENDIX}

To retrieve the negotiated wage equilibrium we depart from the first order condition (9). First we compute $V_{w}$ as

$$
V_{w}=\frac{\partial V}{\partial w_{t}}=\frac{\partial l_{t}}{\partial w_{t}}\left[w_{t}\left(1-\tau^{l}+\phi_{t} \sigma_{t}\right)-S_{t}\left(1-\lambda \tau^{l}\right)\right]+l_{t}\left(1-\tau^{l}+\phi_{t} \sigma_{t}\right),
$$

so that it is easy to calculate $\frac{V_{w}}{V}$ :

$$
\frac{V_{w}}{V}=\frac{\frac{\partial l_{t}}{\partial w_{t}}\left[w_{t}\left(1-\tau^{l}+\phi_{t} \sigma_{t}\right)-S_{t}\left(1-\lambda \tau^{l}\right)\right]+l_{t}\left(1-\tau^{l}+\phi_{t} \sigma_{t}\right)}{l_{t}\left[w_{t}\left(1-\tau^{l}+\phi_{t} \sigma_{t}\right)-S_{t}\left(1-\lambda \tau^{l}\right)\right]} .
$$

To obtain $\frac{\Pi_{w}}{\Pi}$ we begin, analogously, by computing $\Pi_{w}$ :

$$
\Pi_{w}=\left(1-\frac{1}{\eta}\right) y_{t}^{-\frac{1}{\eta}} \frac{\partial y_{t}}{\partial l_{t}} \frac{\partial l_{t}}{\partial w_{t}}-\frac{\partial l_{t}}{\partial w_{t}} w_{t}\left(1+\tau^{e}\right)-l_{t}\left(1+\tau^{e}\right)
$$

Next we replace the first order condition $\left(\Pi_{l}=0\right)$ in expression $(22)$, which then reduces to:

$$
\Pi_{w}=-l_{t}\left(1+\tau^{e}\right) .
$$

Hence, taking into account (4) $\frac{\Pi_{w}}{\Pi}$ can be expressed as

$$
\frac{\Pi_{w}}{\Pi}=\frac{-\left(1-\frac{1}{\eta}\right) \alpha}{w_{t}\left[1-\left(1-\frac{1}{\eta}\right) \alpha\right]}
$$

Substituting the equations (21) and (24) into (9), it follows that

$$
\begin{aligned}
\Omega_{w}= & 0=\beta\left[\frac{\frac{\partial l_{t}}{\partial w_{t}}\left[w_{t}\left(1-\tau^{l}+\phi_{t} \sigma_{t}\right)-S_{t}\left(1-\lambda \tau^{l}\right)\right]+l_{t}\left(1-\tau^{l}+\phi_{t} \sigma_{t}\right)}{l_{t}\left[w_{t}\left(1-\tau^{l}+\phi_{t} \sigma_{t}\right)-S_{t}\left(1-\lambda \tau^{l}\right)\right]}\right] \\
& -(1-\beta)\left[\frac{\left(1-\frac{1}{\eta}\right) \alpha}{w_{t}\left[1-\left(1-\frac{1}{\eta}\right) \alpha\right]}\right] .
\end{aligned}
$$

Then, multiplying this expression by $w_{t}$ yields

$$
\begin{aligned}
\Omega_{w}= & 0=\beta\left[\frac{\partial l_{t}}{\partial w_{t}} \frac{w_{t}}{l_{t}}+\frac{w_{t}\left(1-\tau^{l}+\phi_{t} \sigma_{t}\right)}{\left[w_{t}\left(1-\tau^{l}+\phi_{t} \sigma_{t}\right)+S_{t}\left(1-\lambda \tau^{l}\right)\right]}\right] \\
& -(1-\beta)\left[\frac{\left(1-\frac{1}{\eta}\right)(1-\alpha)}{\frac{1}{\eta}}\right] .
\end{aligned}
$$

After some manipulations and terms rearrangements we retrieve the expression for the equilibrium wage (10). 